\title{
Fertility management for tomato production on an extensive green roof
}

\author{
N. A. Ouellette' ${ }^{1}$ S. A. Walters ${ }^{2}$, K. S. Midden ${ }^{3}$ \\ ${ }^{1}$ Graduate Student, Southern Illinois University, Carbondale, IL, nickolis.ouellette@ gmail.com \\ 2Professor, Southern Illinois University, Carbondale, IL, awalters@ siu.edu \\ 3Professor, Southern Illinois University, Carbondale, IL, kmidden@ @iu.edu
}

Ouellette, N., Walters, S.A., Midden, K.S., 2013. Fertility management for tomato production on an extensive green roof. Journal of Living Architecture. 1(1): 1-14.

http://greenroofs.org/resources/JOLA2013Volume1(Issue1)Ouellette(etal) 


\begin{abstract}
Green roofs offer an alternative growing space to provide fresh vegetable products to urban markets. The soil component is an important aspect of efficient green roof production systems and adequate fertility levels are often lacking in media that are required to maximize plant growth. This research project evaluated four fertilizer treatments on 'Bush Champion II' tomato (Solanum lycopersicum) growth and yield in a $7.62 \mathrm{~cm}$ green roof production system: (1) vermicompost tea, 2) Miracle-Gro fertilizer, 3) Organic Miracle-Gro fertilizer, and 4) no fertilizer. Treatments were applied weekly and ripe tomato fruit was harvested from June to August. Results indicated that Miracle-Gro® provided the highest total tomato fruit yield, which was 30\% and 50\% more in 2011 and 2012, respectively, compared to the next highest treatment Organic Miracle-Gro®. Plant vigor, chlorophyll content, and tomato yields indicated that tomatoes can be successfully grown in a $7.62 \mathrm{~cm}$ green roof medium when given adequate fertilizer applications.
\end{abstract}

Keywords: extensive green roof, green roof agriculture, roof top vegetable production, vermicompost tea

\title{
Introduction
}

Rooftop gardens around the world are now providing produce to consumers at local restaurants and markets (Kortright 2006) and are becoming an important part of the recent rejuvenation of urban agriculture. According to Gaglione and Bass (2010), growing vegetables on rooftops should not be a replacement to rural agriculture, but an enhancement to the urban food movement by providing another source of local, fresh foods (Growing Power Inc. 2010; Tomalty and Komorowski 2010). Rooftop gardens also offer the opportunity to socially interconnect communities and provide local produce in inaccessible locations within the building envelope (Peck 2010). They facilitate the connection of fragmented landscapes, not only by increasing the urban biodiversity, but also through insulating buildings, providing residents with local produce (Michigan State University 2011; Peck 2010) and generating interest/enthusiasm in environmental sustainability.

There are tremendous opportunities for growing vegetables on roofs, although structural weight constraints of the building must be taken into consideration. For example, the composition of a green roof medium directly affects runoff and roof weight load capacities. Slower moisture infiltration rates increase weight loads on roofs compared to media with faster rates (Rowe and Getter 2010; Werthmann 2007). Therefore, choosing a more porous aggregate such as light weight aggregate or pumice is important where precipitation may be high, although it can be difficult to sustain plant growth in these environments with the excess leaching of nutrients (Rowe and Getter 2010). However, when fertilizers are applied to improve plant growth, nutrient leaching or runoff may be a problem if water retention practices are not utilized (Snodgrass and Mclntyre 2010). 
Vegetable production may also be possible on retrofitted green roofs in a minimal growing substrate depth with intensive seasonal maintenance, especially additions of water and supplemental nutrients (Snodgrass and Mclntyre 2010). Extensive-type green roof media may provide high organic matter and supplemental nutrient content depending upon the mix and concentration of the green roof media. However, since most vegetables prefer deeper soil, green roofs with greater rooting depths have been considered as best suited for their production.

Nutrient management systems play an important role in green roof vegetable production. Fertility practices are an important part of being successful in both intensive and extensive green roof systems. Consistent fertility levels in the medium during the growing season with use of supplemental nutrients will produce higher vegetable crop yields. Compost is a preferred source of an organic amendment for green roof substrates due to its high nutrient content, microbial population and recycling value (Mather 2006). However, nutrient use efficiency from these products is probably low for several reasons including problems of leaching and nutrients in nonavailable forms. The application of nutrients from compost teas may prove over several years to be a useful fertilizer delivery method since it may build green roof soils through increasing soil microbial populations and cation-exchange capacities of plant available nutrients (Adi and Noor 2009; Alexander 2004; Mather 2006), while keeping building weight constraints at a low level.

Rooftop farms such as Brooklyn Grange grow hundreds of thousands of vegetable plants each season, although tomatoes are grown the most with 40 different varieties planted (Brooklyn Grange 2010). Tomatoes, always in high demand in North American markets, play a crucial role to the success of roof top production by generating high revenues. Lettuce and other greens have also shown to be important roof top crops and have high productivity in rooftop agriculture with minimal soil depths (GRACE Communication Foundation 2010). Rooftop agriculture has potential to supply restaurants and local markets with fresh, healthy, sustainable food products and also connect urban consumers with their food (Elstein et al. 2008). Urban agriculture has a chance to change the way our food is distributed in and around the city, and potentially offer better quality vegetables than what is currently available (Elstein et al. 2008).

Green roof media may not contain optimal fertility needed for adequate vegetable production and the success of roof top vegetable production often depends on fertility management systems (Bisgrove 2010) to create optimal growing conditions. Thus a study was conducted to determine the influence of four fertilizer treatments to improve tomato productivity on an extensive green roof. The objectives of this research were to: 1) determine if tomatoes will grow and successfully develop in a $7.62 \mathrm{~cm}$ extensive green roof media, and 2) determine the effect of $\mathrm{N}$ fertilizer management practices on tomato growth characteristics and yield.

\section{Materials and Methods}

An experiment was conducted on the $343.74 \mathrm{~m}^{2}$ extensive green roof on the College of Agricultural Sciences building at Southern Illinois University in Carbondale, Illinois (SIUC) during 2011 and 2012. The extensive green roof at SIUC is a layered system obtained from Green Roof Solutions (Glenview, Illinois) that consists of (starting at the bottom portion of roof): waterproof membrane, protection fabric, root permeable layer, drainage layer, filter fabric, 
growing medium and vegetation layer. The drainage layer consists of a plastic tray system that collects and drains excess water from the roof. An edging system enclosed the layers topped by 7.5 to $10 \mathrm{~cm}$ of an extensive green roof medium (GRM) obtained from Midwest Trading Company (Virgil, Illinois). The GRM is primarily mineral based, containing various gradations of expanded lightweight clay aggregate (LWA) with 4 to $5 \%$ compost and $0.91 \mathrm{~kg} / \mathrm{m}^{3} \mathrm{slow}$ release nitrogen fertilizer ( $\mathrm{Nu}$-Gro America Corporation, Brantford, Ontario) and $3.63 \mathrm{~kg} / \mathrm{m}^{3}$ of iron sulfate $\left(\mathrm{FeSO}_{4}\right)$ (Hercules Powder Company, Wilmington, DE).

The GRM used on the SIUC green roof is typical of most extensive green roofs, although types of soil-less media, nutrient content, and percentages of organic matter may slightly differ. The SIUC green roof system weighs about $9.98 \mathrm{~kg} / \mathrm{m}^{2}$ and based on engineering specifications, the SIUC green roof can hold up to $11.34 \mathrm{~kg} / \mathrm{m}^{2}$ of plants and media. Prior to planting and to disperse nutrients in the medium from the experiment conducted the previous year, all GRM was removed, mixed and re-laid on the roof. Two GRM samples were collected from the green roof in April 2011 and 2012 and sent to Brookside Laboratories, Inc. (New Knoxville, OH) for nutrient analysis (Table 1).

Table 1. Green roof medium analysis for 2011 and 2012 prior to establishment of tomato fertilizer experiment.

\begin{tabular}{lcccccccccc}
\hline Year & & ME/100 g & \% & \multicolumn{7}{c}{ Nutrient content in ppm } \\
\hline & $\mathrm{pH}$ & $\mathrm{CEC}^{\mathrm{z}}$ & $\mathrm{OM}^{\mathrm{y}}$ & $\mathrm{N}$ & $\mathrm{P}$ & $\mathrm{K}$ & $\mathrm{Ca}$ & $\mathrm{Mg}$ & $\mathrm{NO3}-\mathrm{N}$ & $\mathrm{NH} 4-\mathrm{N}$ \\
$\mathbf{2 0 1 1}$ & 7.5 & 9.9 & 4.8 & 48.8 & 97.0 & 121.0 & 1422.0 & 218.0 & 20.9 & 19.1 \\
$\mathbf{2 0 1 2}$ & 7.2 & 12.1 & 4.7 & 48.0 & 116.5 & 119.5 & 1724.5 & 286.0 & 14.0 & $<0.5$ \\
\hline
\end{tabular}

${ }^{\mathrm{r}} \mathrm{CEC}$ is Cation Exchange Capacity.

yOM is Organic Matter.

The experiment was setup as a randomized complete block design with 5 replications evaluating four fertilizer treatments on 'Bush Champion II' tomato growth and productivity. The block design was to account for variations in the roof drainage pattern. This tomato cultivar was chosen for its smaller compact plant size $(0.61 \mathrm{~m}$ at maturity) and the large fruit-size produced $(\sim 0.23 \mathrm{~kg}$ on average). Each fertilizer application amount followed standard recommendations to simulate procedures that would be used by the public. The fertilizer treatments evaluated were: 1) vermicompost tea (VCT; from composted coffee grounds); 2) Miracle-Gro fertilizer (MG; Scotts Miracle-Gro Products Inc., Maryville, OH); 3) Organic Miracle-Gro fertilizer (OMG; Scotts Miracle-Gro Products Inc.); and 4) and no fertilizer $(0 \mathrm{mg} / \mathrm{kg} \mathrm{N})$. Liquid samples of each fertilizer treatment were also sent to Brookside Laboratories, Inc. for nutrient analysis (Table 2). 
Table 2. Nutrient content of fertilizer treatments applied weekly to tomatoes in green roof experiment.

\begin{tabular}{lcccccc}
\hline $\begin{array}{l}\text { zFertilizer } \\
\text { Treatments }\end{array}$ & \multicolumn{7}{c}{ Nutrient content in ppm } \\
\hline OM & $\mathrm{N}$ & $\mathrm{P}$ & $\mathrm{K}$ & $\mathrm{Ca}$ & $\mathrm{Mg}$ & $\mathrm{Na}$ \\
\cline { 2 - 7 } & 6900 & $<100$ & 70 & $<200$ & $<50$ & $<50$ \\
T & 16100 & 410 & 1110 & $<200$ & $<50$ & $<50$ \\
& 12600 & $<100$ & 310 & $<200$ & $<50$ & $<50$ \\
\hline
\end{tabular}

${ }^{\mathrm{z} F e r t i l i z e r ~ t r e a t m e n t s ~ w e r e ~ O M ~ i s ~ O r g a n i c ~ M i r a c l e-G r o, ~} \mathrm{M}$ is Miracle-Gro and T is vermicompost tea.

The VCT was made from coffee ground-based vermicompost prepared at the SIUC Center for Sustainable Farming. The VCT was prepared by placing vermicompost in daily-aerated water at a 1:5 ratio. After 48 hours, the liquid was strained through cheesecloth to remove solids before applying as a liquid drench around plants. All fertilizer applications initially consisted of $50 \mathrm{ml}$ of solution per plant, but after the first 3 weeks, the amount of solution applied to plants increased to $1.9 \mathrm{~L}$ per plant until the end of harvest. However, the $50 \mathrm{ml}$ and $1.9 \mathrm{~L}$ contained the same amount of nutrients; the nutrients in the $1.9 \mathrm{~L}$ were in a more diluted form.

'Bush Champion II' tomato seeds were planted in a greenhouse in early March during 2011 and 2012. Seedlings at the 4- to 5-leaf stage were transplanted during late March each year into $10.16 \mathrm{~cm}$ dia. plastic pots that contained peat moss, vermiculite and perlite in a 1:1:1 ratio. A weekly application of $50 \mathrm{ml}$ of the specific fertility treatment identical to what would be used on the green roof was applied to seedlings. Once plants had reached the 10- to 12-leaf stage, tomato plants were hardened-off for about 5 days in an outdoor coldframe prior to transplanting into the greenroof medium during mid-April. Four tomato plants were grown in each plot using $0.61 \mathrm{~m}$ in-row spacing with $1.22 \mathrm{~m}$ centers. Since the extensive medium dried out quickly, drip irrigation was used daily during the growing season. A supporting structure made of $1.90 \mathrm{~cm}$ plastic PVC piping was installed along with twine and chicken wire to secure plants and keep them upright on the roof. Two lines of twine starting at $15.24 \mathrm{~cm}$ from the soil surface and again at $30.48 \mathrm{~cm}$ were strung through the supporting structures to provide tomato plant support. Insects and diseases were controlled with standard foliar applications of Pyrethrin (Pyganic; MGK, Minneapolis, MN) and chlorothanil (Bravo; Zeneca, Wilmington, DE) at 10-d intervals starting within 2 weeks of transplanting (Egel et al. 2010).

Tomato plant height and leaf chlorophyll measurements were taken in June, July and August each year. Tomato plant heights $(\mathrm{cm})$ were determined from the soil surface to the plant terminus. Leaf chlorophyll content was obtained using a Konica Minolta SPAD-502 chlorophyll meter (Special Products Analysis Division, Konica Minolta Sensing, Inc., Osaka, Japan) on five mature leaves near the center portion of each plant in a plot. Tomato fruit were hand-harvested with yield (number and weight of marketable and cull fruit) collected from eight weekly harvests. Harvests began mid-June and ended mid-August for both years. 
Data were subjected to analysis of variance procedures appropriate for a randomized complete block experimental design using the GLM procedure of SAS (SAS Inst., Cary, N.C.). Data were analyzed to determine if year by treatment interactions were present. Fisher's least protected significant difference test was used to separate fertility treatment differences at $\mathrm{P} \leq 0.05$.

\section{Results}

Year by treatment interactions were detected $(\mathrm{P} \leq 0.05)$ for tomato growth and yield parameters. Therefore, treatment data for these parameters are shown by year (Tables 3, 4, 5, 6 and 7). Stunted growth from inclement weather conditions in 2011 may have caused the year differences, although fertility treatments responses were similar over the two years. Early season stormy and high wind weather conditions resulted in some crop destruction in 2011.

\section{TOMATO PLANT HEIGHTS}

The inclement weather of high temperatures and severe storms observed throughout the 2011 growing season resulted in reduced plant heights compared to 2012. The no fertilizer (control) differed from all other fertilizer treatments with lower plant heights during the early season in 2011; however, no differences were detected $(\mathrm{P} \geq 0.05)$ among the three fertilizer applications. In 2012, tomato plants treated with Miracle-Gro® and Organic Miracle-Gro® had over $7.62 \mathrm{~cm}$ more growth than VCT or the no fertilizer treatment (Table 3). Mid-season differences between treatments were similar to that observed during the early-season, although greater tomato plant height separations became more apparent as the season progressed due to the added fertility. By the end of the season, tomato plants treated with Miracle-Gro had the greatest plant height compared to any other treatment and differed from the no fertilizer treatment by almost $25.40 \mathrm{~cm}$ and $50.9 \mathrm{~cm}$ in 2011 and 2012, respectively (Table 3).

Table 3. Tomato plant height as influenced by four fertilizer treatments in an extensive green roof production system during 2011 and 2012.

\begin{tabular}{ccccccc}
\hline Fertility Treatments & \multicolumn{2}{c}{$\begin{array}{c}\text { Plant Height }(\mathbf{c m}) \\
\text { Early Season }\end{array}$} & \multicolumn{2}{c}{$\begin{array}{c}\text { Plant Height (cm) } \\
\text { Mid-Season }\end{array}$} & \multicolumn{2}{c}{$\begin{array}{c}\text { Plant Height (cm) } \\
\text { Late Season }\end{array}$} \\
\hline & 2011 & 2012 & 2011 & 2012 & 2011 & 2012 \\
\hline Miracle-Gro® & $27.43 \mathrm{a}$ & $43.94 \mathrm{a}$ & $75.56 \mathrm{a}$ & $84.20 \mathrm{a}$ & $78.35 \mathrm{a}$ & $101.21 \mathrm{a}$ \\
Organic Miracle- & $29.59 \mathrm{a}$ & $35.81 \mathrm{~b}$ & $71.62 \mathrm{a}$ & $72.77 \mathrm{~b}$ & $75.43 \mathrm{a}$ & $80.77 \mathrm{~b}$ \\
$\quad$ Gro ${ }^{\circledR}$ & & & & & & \\
Vermicompost Tea & $28.70 \mathrm{a}$ & $27.30 \mathrm{c}$ & $58.03 \mathrm{~b}$ & $62.86 \mathrm{c}$ & $67.69 \mathrm{~b}$ & $67.31 \mathrm{c}$ \\
$\quad$ No Fertilizer & $24.13 \mathrm{~b}$ & $26.54 \mathrm{c}$ & $51.99 \mathrm{c}$ & $53.34 \mathrm{~d}$ & $57.22 \mathrm{c}$ & $55.37 \mathrm{~d}$ \\
\hline
\end{tabular}

Means within the same column of the table followed by the same letter do not differ significantly according to Fisher's protected least significant difference (LSD) test $(\mathrm{P} \leq 0.05)$.

\section{LEAF CHLOROPHYLL CONTENT}

Tomatoes treated with Miracle-Gro® and Organic Miracle-Gro® had similar leaf chlorophyll content during the early-season, although both differed from the lower chlorophyll amounts provided by the VCT and no fertilizer treatment. During the mid-and late-season, tomatoes 
treated with Miracle-Gro® were greater $(\mathrm{P} \leq 0.05)$ than those treated with Organic MiracleGro®, although tomatoes treated with Organic Miracle-Gro® was greater than those treated with VCT and the no fertilizer treatment (Table 4). The tomatoes treated with Miracle-Gro® had the greatest amount of tomato leaf chlorophyll content which is a direct indication of the nitrogen content in the plant.

Table 4. Tomato plant leaf chlorophyll content at early-, mid-, and late-season as influenced by four fertilizer treatments in an extensive green roof production system during 2011 and 2012.

\begin{tabular}{ccccccc}
\hline Fertility Treatments & \multicolumn{2}{c}{$\begin{array}{c}\text { Leaf Chlorophyll } \\
\text { Content } \\
\text { Early-Season }\end{array}$} & \multicolumn{2}{c}{$\begin{array}{c}\text { Leaf Chlorophyll } \\
\text { Content } \\
\text { Mid-Season }\end{array}$} & \multicolumn{2}{c}{$\begin{array}{c}\text { Leaf Chlorophyll } \\
\text { Content } \\
\text { Late-Season }\end{array}$} \\
\hline & 2011 & 2012 & 2011 & 2012 & 2011 & 2012 \\
\hline Miracle-Gro® & $55.32 \mathrm{a}$ & $49.20 \mathrm{a}$ & $61.70 \mathrm{a}$ & $76.50 \mathrm{a}$ & $67.68 \mathrm{a}$ & $74.42 \mathrm{a}$ \\
Organic Miracle- & $51.56 \mathrm{ab}$ & $48.14 \mathrm{a}$ & $52.68 \mathrm{~b}$ & $51.78 \mathrm{~b}$ & $53.02 \mathrm{~b}$ & $55.24 \mathrm{~b}$ \\
$\quad$ Gro® & & & & & & \\
Vermicompost Tea & $42.40 \mathrm{bc}$ & $24.16 \mathrm{~b}$ & $45.44 \mathrm{c}$ & $39.96 \mathrm{c}$ & $45.80 \mathrm{~b}$ & $47.30 \mathrm{c}$ \\
$\quad$ No Fertilizer & $37.9 \mathrm{c}$ & $20.80 \mathrm{~b}$ & $33.74 \mathrm{~d}$ & $33.76 \mathrm{c}$ & $26.60 \mathrm{c}$ & $32.84 \mathrm{~d}$ \\
\hline
\end{tabular}

Means within the same column of the table followed by the same letter do not differ significantly according to Fisher's protected least significant difference (LSD) test $(\mathrm{P} \leq 0.05)$.

\section{TOMATO FRUIT YIELDS}

Tomato fruit yields differed among fertility treatments. Although those treated with Organic Miracle-Gro® provided increased amounts of growth and yields, that treatment had the lowest percentage of marketable fruit in 2011 and 2012 (Table 5); this resulted in the greatest number of culls and lowest marketable fruit yields. Less marketable fruit yields resulted from lower plant biomass primarily from reduced foliage cover that led to excessive amounts of sunscald on fruit. Tomatoes treated with VCT provided the greatest percentage of marketable fruit yields, although it had much lower fruit yields. 
Table 5. Percent marketable tomato fruit yield as influenced by four fertilizer treatments in an extensive green roof production system.

\begin{tabular}{lcc}
\hline Fertility Treatments & \% Marketable Fruit & \% Marketable Fruit \\
& $\mathbf{2 0 1 1}$ & $\mathbf{2 0 1 2}$ \\
\hline Miracle-Gro® & $60.08 \mathrm{~b}$ & $63.16 \mathrm{a}$ \\
Organic Miracle-Gro® & $54.34 \mathrm{c}$ & $38.29 \mathrm{c}$ \\
Vermicompost Tea & $63.68 \mathrm{a}$ & $62.26 \mathrm{a}$ \\
No Fertilizer & $55.98 \mathrm{c}$ & $56.53 \mathrm{~b}$ \\
\hline Means within same column of the table followed by the same letter do not differ significantly \\
according to Fisher's protected least significant difference (LSD) test $(\mathrm{P} \leq 0.05)$.
\end{tabular}

For early-season tomato harvests, tomatoes treated with Miracle-Gro® provided the greatest total yield during both years, although this treatment did not differ from those treated with Organic Miracle-Gro® in 2011. In contrast, tomatoes treated with VCT and the no fertilizer treatment produced the lowest total yields in both years (Tables 6 and 7). Moreover, tomatoes treated with Miracle-Gro® produced greater tomato fruit yields among the four fertilizer treatments for late season harvests. During the late-season, tomatoes treated with VCT provided greater tomato fruit yields in 2012 than 2011, as well as providing greater tomato fruit yields than tomatoes treated with Organic Miracle-Gro® and the no fertilizer treatment. For the entire growing season, tomatoes treated with Miracle-Gro® as a fertilizer source produced about $4.53 \mathrm{~kg}$ and $7.26 \mathrm{~kg}$ fruit/plant in 2011 and 2012, respectively, while those treated with VCT produced much lower fruit yields with approximately $0.91 \mathrm{~kg}$ and $2.26 \mathrm{~kg}$ fruit per plant in 2011 and 2012, respectively. Of all fertilizer treatments, Miracle-Gro® provided the greatest total tomato fruit yield, which was 30\% and 50\% more in 2011 and 2012, respectively, compared to the next greatest treatment - Organic Miracle-Gro®.

Table 6. Tomato fruit yield (kg/plant) as influenced by four fertilizer treatments in an extensive green roof production system during 2011.

\begin{tabular}{cccccccccc}
\hline Fertility Treatments & \multicolumn{2}{c}{$\begin{array}{c}\text { Early Season } \\
\text { Harvest } \\
\text { (kg fruit/plant) }\end{array}$} & \multicolumn{2}{c}{$\begin{array}{c}\text { Late Season } \\
\text { Harvest } \\
\text { (kg fruit/plant) }\end{array}$} & \multicolumn{2}{c}{$\begin{array}{c}\text { Total Season } \\
\text { Harvest } \\
\text { (kg fruit/plant) }\end{array}$} \\
\hline & Mark & Cull & Total & Mark & Cull & Total & Mark & Cull & Total \\
\hline $\begin{array}{c}\text { Miracle-Gro® } \\
\text { Organic Miracle- }\end{array}$ & $1.05 \mathrm{a}$ & $0.79 \mathrm{a}$ & $1.84 \mathrm{a}$ & $1.78 \mathrm{a}$ & $1.10 \mathrm{a}$ & $2.88 \mathrm{a}$ & $2.84 \mathrm{a}$ & $1.88 \mathrm{a}$ & $4.72 \mathrm{a}$ \\
$\begin{array}{c}\text { Gro® } \\
\text { Vermicompost Tea }\end{array}$ & $0.40 \mathrm{~b}$ & $0.19 \mathrm{~b}$ & $0.60 \mathrm{~b}$ & $0.30 \mathrm{~b}$ & $0.21 \mathrm{c}$ & $0.51 \mathrm{c}$ & $0.71 \mathrm{c}$ & $0.40 \mathrm{bc}$ & $1.11 \mathrm{c}$ \\
$\begin{array}{c}\text { No Fertilizer } \\
\text { Non }\end{array}$ & $0.40 \mathrm{~b}$ & $0.29 \mathrm{~b}$ & $0.78 \mathrm{~b}$ & $0.45 \mathrm{~b}$ & $0.44 \mathrm{bc}$ & $0.89 \mathrm{c}$ & $0.93 \mathrm{bc}$ & $0.73 \mathrm{~b}$ & $1.67 \mathrm{c}$
\end{tabular}

Means within the same column followed by the same letter do not differ significantly according to Fisher's protected least significant difference (LSD) test $(\mathrm{P} \leq 0.05)$. Early-season is harvest 1-4; late-season is harvest 4-8 total season is all 8 harvest in 2011. 
Table 7. Tomato fruit yield (kg/plant) as influenced by four fertilizer treatments in an extensive green roof production system during 2012.

\begin{tabular}{ccccccccccc}
\hline Fertility Treatments & \multicolumn{2}{c}{$\begin{array}{c}\text { Early Season } \\
\text { Harvest } \\
\text { (kg fruit/plant) }\end{array}$} & \multicolumn{2}{c}{$\begin{array}{c}\text { Late Season } \\
\text { Harvest } \\
\text { (kg fruit/plant) }\end{array}$} & \multicolumn{2}{c}{$\begin{array}{c}\text { Total Season } \\
\text { Harvest } \\
\text { (kg fruit/plant) }\end{array}$} \\
\hline & Mark & Cull & Total & Mark & Cull & Total & Mark & Cull & Total \\
\hline $\begin{array}{c}\text { Miracle-Gro® } \\
\text { Organic }\end{array}$ & $3.22 \mathrm{a}$ & $1.81 \mathrm{a}$ & $5.03 \mathrm{a}$ & $1.23 \mathrm{a}$ & $0.80 \mathrm{a}$ & $4.48 \mathrm{a}$ & $4.40 \mathrm{a}$ & $2.60 \mathrm{a}$ & $7.06 \mathrm{a}$ \\
$\begin{array}{c}\text { Miracle-Gro® } \\
\text { Vermicompost Tea }\end{array}$ & $0.53 \mathrm{~b}$ & $1.40 \mathrm{ab}$ & $1.93 \mathrm{~b}$ & $0.73 \mathrm{ab}$ & $0.63 \mathrm{ab}$ & $3.00 \mathrm{~b}$ & $1.26 \mathrm{~b}$ & $2.03 \mathrm{a}$ & $3.30 \mathrm{~b}$ \\
$\begin{array}{c}\text { No Fertilizer } \\
\text { No }\end{array}$ & $0.44 \mathrm{~b}$ & $0.40 \mathrm{~b}$ & $0.85 \mathrm{~b}$ & $0.57 \mathrm{~b}$ & $0.83 \mathrm{~b}$ & $0.95 \mathrm{c}$ & $1.02 \mathrm{~b}$ & $1.73 \mathrm{c}$ & $1.80 \mathrm{c}$ \\
\hline
\end{tabular}

Means within the same column followed by the same letter do not differ significantly according to Fisher's protected least significant difference (LSD) test $(\mathrm{P} \leq 0.05)$. Early-season is harvest 1-4; late-season is harvest 4-8 total season is all 8 harvest in 2012.

Tomato plant height, leaf chlorophyll, and fruit yields were generally greater $(\mathrm{P} \leq 0.05)$ when Miracle-Gro ${ }^{\circledR}$ and Organic Miracle-Gro ${ }^{\circledR}$ were used as the fertilizer source compared to the no fertilizer treatment and VCT (Tables 3, 4, 5, 6, and 7). Although, tomatoes treated with MiracleGro and VCT had $16,100 \mathrm{mg} / \mathrm{kg}$ and $12,600 \mathrm{mg} / \mathrm{kg} \mathrm{N}$ content, respectively, plant available phosphorus and potassium were much higher in tomatoes treated with Miracle-Gro® compared to the VCT treatment (Table 2). The plant available mineral nutrients applied to the GRM had a direct influence on most tomato growth parameters evaluated. However, percent marketable yield was greater when VCT was utilized as the fertilizer source (Table 5).

\section{Discussion}

Results from this study indicated that 'Bush Champion II' tomato growth and yield increased with greater amounts of nutrients that were readily available for plant uptake. Generally, there tended to be an increase in plant height, leaf chlorophyll content and total tomato fruit yields regardless of the fertilizer source compared to the no-fertilizer treatment. Thus, Miracle-Gro, ${ }^{\circledR}$ Organic Miracle-Gro®, and VCT treatments were essential to provide nutrients needed to enhance tomato plant growth when grown in a three inch extensive green roof media. Based on our study, it can be concluded that with recommended standard applications (1) Miracle-Gro® generally provided the greatest amounts of tomato growth and yield; (2) Organic Miracle-Gro® generally provided the second greatest amount of tomato growth and yield, although it did produce the greatest percentage of cull fruit; (3) VCT resulted in the least amount of tomato growth and yield of the fertilizer treatments which was most likely due to $\mathrm{N}$ being in an unavailable form for uptake or leaching of $\mathrm{N}$ through the medium before being readily available for plant uptake; and, (4) the no fertilizer treatment provided the lowest amounts of growth and yield which resulted from low amounts of nutrients present in extensive green roof media throughout the growing season. Table 2 in this study displays the $\mathrm{N}$ in each treatment, which was 
applied, but unavailable and leached $\mathrm{N}$ was not measured. That evaluation is recommended for future studies. Overall, tomato plants were relatively disease and pest free, although plants grown with VCT were generally healthier in their appearance compared to tomatoes receiving the other treatments. Atiyeh et al. (2000) indicated that VCT can be used as a mineralized organic material to improve plant growth and productivity. In our study, the VCT resulted in greater yields and growth parameters in 2012 as compared to 2011, respectively (Tables 4, 6, and 7), which may have been due to an increase in aeration of the VCT solution resulting in healthier microbes and mineral nutrients present in the fertility solution. When VCT is mixed properly, it has increased levels of beneficial microorganisms that will increase root growth, and plant growth-regulating materials, such as plant growth hormones and humic acids, that will increase plant productivity (Arancon et al. 2003; Brady and Weil 2008). However, when used on an extensive green roof system, the organic forms of the minerals present in VCT may leach out of the green roof media before they are broken down into a form that the plant can use.

'Bush Champion II' tomato plants responded well when high amounts of readily available $\mathrm{N}$ were frequently applied. Miracle-Gro® had the highest amount of nitrogen applied with 16,100 $\mathrm{mg} / \mathrm{kg}$, and although VCT had $12,600 \mathrm{mg} / \mathrm{kg}$, most was in the organic form and was not readily available for plant uptake. Organic fertilizers differ from inorganic fertilizer in that organic ones are made up of substances that take more time to break down into usable forms by the plant and may be treated as a slow-release type. It is not advised to apply organic fertilizers at excessive rates as this could cause injury to the plant and environmental degradation (Rosen and Eliason 2005). Although compost is a widely used amendment in green roof media (Snodgrass and Snodgrass 2006), more research is needed to determine the optimal percentages required in the medium, while at the same time making sure not to exceed the restricted roof and runoff specifications needed for green roof vegetable production. The concern of exceeding the weight limit on the SIUC roof limited any use of additional compost; therefore, liquid application of vermicompost tea was required to evaluate vermicompost as a type of fertilizer. Moreover, the green roof media can be tailored specifically to the plant or crop species. According to Friedrich and Buist (2008), green roof media is a specialized substrate that stabilizes the plant roots and provides optimal growing conditions for plant growth. It may be possible that the mineral nutrients can be recycled and used through a drip system to recycle mineral nutrients and enhance soil fertility and reduce wasted runoff on a green roof. Unfortunately, due to the internal drainage system dating the early 1950's roof on the SIUC Agriculture building and other obstacles, it was not feasible to recycle and evaluate this option. The fabrication and design of the medium should be altered towards the physiology of the crops intend for production (Friedrich and Buist 2008). Factors that affected the quality and yield of the tomato fruits may have been attributed to the deficiency of nutrient uptake with the coarseness of the gradations, depth of media, and the climate present on the roof. The use of organic amendments has shown to improve soil structure, enhance soil fertility and increase moisture-holding capacity of most highly inorganic media (Arancon et al. 2003). Although problems arise with the biodegradation of these materials over time often resulting in the shrinkage of media, continual additions of organic amendments are needed to balance the physical properties of growing media. Consequently, care is required when adding additional amendments in order to not exceed proposed weight constraints for a green roof. 
The plant available mineral nutrients applied to the GRM have a direct influence on horticultural crop growth (Dunnett and Kingsbury 2008; Brady and Weil 2008; Elstein et al. 2008; Getter and Rowe 2006), and in our green roof study, Miracle-Groß exceeded all other treatments for tomato growth and fruit production which was due to the nutrients being in a form that was readily available for plant uptake while also following application recommendations. This indicates that high tomato fruit yields may be possible in an extensive green roof system if heavy fertility applications are used; however, more research should be conducted with these and other sustainable and organic fertilizer applications using different media sources to determine the optimal system to use for tomatoes or other vegetables grown in an extensive green roof. Although our analysis indicated that the VCT had high amounts of nitrogen, most was in the organic form and was not readily available for plant uptake, similar to other studies (Adi and Noor 2009; Alexander 2004; Dinsdale et al. 1996). In our study, plants fertilized with MiracleGro ${ }^{\circledR}$ also had significantly higher chlorophyll content compared to all other fertilizer treatments (Table 4). Subsequently, the no fertilizer and VCT applications resulted in less tomato fruit production on an extensive green roof, as lower fertility and less plant availability of nutrients in these treatments reduced tomato plant vigor and fruit yield.

Extensive roofs tends to be most suited for many retrofitted roofs or those with low weight restrictions (Dunnett and Kingsbury 2008). Traditionally, these roofs grew drought tolerant species but they also have potential for growing vegetables, especially if the roof remains accessible for continual maintenance during the growing season (Sharp et al. 2008). Michigan State University conducted a study over the 2009 to 2011 growing seasons evaluating three growing systems, including an extensive green roof. Their study concluded that it is possible to produce tomatoes and other vegetables and herbs on extensive green roofs with irrigation and minimal fertilizer applications (Whittinghill et al. 2013). Extensive media consists of coarse inert and organic materials; and, this growing medium is typically made of lightweight aggregate or shale comprised of mainly $75 \%$ to $90 \%$ inorganic materials and $10 \%$ to $25 \%$ organic materials, which are added for water and nutrient retention and supply (Snodgrass and Snodgrass 2006; VanWoert et al. 2005; Werthmann 2007). Intensive media and extensive media mixes blended with organic or mineral additives (e.g., peat, humus, wood chips, sand, lava, or expanded clay) have shown optimum water retention, permeability, and density necessary to support green roof vegetation (Velazquez 2010) and are most likely well suited for vegetable production. Additional research on green roof media and fertility management systems is a top priority for vegetable production to define how to adjust for weight load limits and other challenges unique to that environment.

\section{Conclusion}

As the world's population becomes increasingly urbanized, food sustainability in urban areas is becoming a more important issue. Unfortunately, land that has traditionally been used for agriculture within urban areas is now in high demand and vulnerable to potential development. As a result, rooftop agriculture (particularly green roof systems) has become an attractive possibility to increase localized urban agriculture. However, green roof technology has yet to be widely adopted in urban agriculture which may be due to the fact that the efficiency and effectiveness of green rooftop agriculture has not been extensively evaluated for rooftop 
production to be successful. Continued research (as this study, Michigan State University and other universities and research facilities have shown) is needed to determine those sustainable practices that will allow the production of safe, high yielding crops that have superior quality characteristics. Furthermore, since most green roof systems are placed on existing structures, allowable weight loads determine the type of system (extensive or intensive) that can be used for vegetable crop production.

This study indicated that retrofitted roofs with extensive media components have potential for tomato production, which is important, as this crop is often in high demand in urban markets. Tomatoes were also selected because they are high nitrogen feeders which aided in evaluating standard organic and inorganic fertilizer treatments typically used for in-ground or container production. Tomato production is definitely possible in a $7.62 \mathrm{~cm}$ extensive green roof media with additional fertility applications. However, for tomato to be more effectively grown in this type of green roof system, a more productive light-weight mineralized medium needs to be developed that can specifically hold more moisture and nutrients, as well as dealing with high winds and temperature extremes. Although this research has shown that tomato yields can be maximized in limited amounts of soil media on a green roof, water and nutrient runoff needs to be considered primarily for recycling these nutrients to develop a more sustainable closed system.

Since nutrient management plays an important role in green roof vegetable systems, further research should be directed at the fertility practices for both intensive and extensive green roof systems with the overall intent of recycling the mineral nutrients through drip irrigation or fertigation systems. Further studies on the long-term value of adding vermicompost tea to a green roof medium should be explored where weight limits restrict the addition of compost. Moreover, determining the growing media that is most suitable for rooftop vegetable production with a focus on improving the nutrient value and water holding capacity of the media is also critical. Several companies, such as Midwest Trading Company® and Rooflite ${ }^{\circledR}$ have recently expanded their media selections for vegetable production on green roofs, although research is needed to determine their applicability to various vegetable production scenarios. Additional green roof vegetable crop research should also focus on the water holding and nutrient holding capacities, as well as runoff potentials for media commonly used in extensive and intensive systems. Thus, it appears that future success of roof top vegetable production will be determined by medium components, fertility management systems and the ability to recycle mineral nutrients to create optimal growing conditions on rooftops.

\section{Literature Cited}

Adi A.J. and Z.M. Noor. "Waste Recycling: Utilization of Coffee Grounds and Kitchen Waste in Vermicomposting." Bioresource Technology 100, no.2 (2009): 1027-1030.

Alexander, R. “Green Roofs Grow with Brown Compost.” Biocycle, 45, no.9 (2004): 55-57.

Arancon, N.Q., C.A. Edwards, P. Bierman, J.D. Metzger, S. Lee, and C. Welch. "Effects of Vermicomposts on Growth and Marketable Fruits of Field-Grown Tomatoes, Peppers and Strawberries." Pedobiologia 47, no. 5-6 (2003): 731-735. 
Atiyeh, R., S. Subler, C. Edwards, G. Bachman, J. Metzger, and W. Shuster. "Effects of Vermicomposts and Composts on Plant Growth in Horticultural Container Media and Soil.” Pedobiologia 44, no. 5 (2000): 579-590.

Bisgrove, R. “Urban Horticulture: Future Scenarios.” Acta Hort. 881, (2010): 33-46.

Brady, N C., and R R. Weil. The Nature and Properties of Soils. 14 ${ }^{\text {th }}$ ed. Pearson/Prentice Hall. Upper Saddle River, NJ: 2008.

Brooklyn Grange. "Brooklyn Grange Farms.” Brooklyn, New York. Accessed December 5, 2012, http://www.brooklyngrangefarm.com.

Dinsdale, R., F. R. Hawkes, and D. L. Hawkes. "The Mesophilic and Thermophilic Anaerobic Digestion of Coffee Waste Containing Coffee Grounds.” Water Research 30, no. 2 (1996): 371-377.

Dunnett, N., and N. Kingsbury. Planting Green Roofs and Living Walls. Portland, Or. Timber Press, 2008.

Egel, D., R. Foster, E. Maynard, R. Weinzierl, M. Babadoost, H. Taber and S. Gu. Midwest Vegetable Production Guide for Commercial Growers." Purdue University Press, 2010.

Elstein, J and others. "Evaluating Growing Media for a Shallow - Rooted Vegetable Crop Protection System on a Green Roof." Acta Horticulturae 782, (2008): 177-183.

Friedrich C. and R. Buist. "The Organic Question When it Comes to Growing Media, There is Considerable Debate as to What Exactly Constitutes the Best Mix for Superior Performance." Living Architecture Monitor 10, no. 1 (2008): 16-21.

Gaglione, S. and B. Bass. "Increasing Urban Food Security with Extensive Green Roofs.” Living Architecture Monitor 12, no. 4 (2010): 26-27.

Getter, K. and B. Rowe. "The Role of Extensive Green Roofs in Sustainable Development." HortScience 41, no. 5 (2006): 1276-1285.

GRACE Communications Foundation. "Sustainable Table - Organic Agriculture." Accessed April 3, 2011, http://www.sustainabletable.org/issues/eatlocal/index_pf.html.

Growing Power Inc. Accessed October 21, 2010, http://growingpower.org.

Kortright, R. "Evaluating the Potential of Green Roof Agriculture.” City Farmer's Urban Agriculture Notes, accessed January 3, 2011, http://www.cityfarmer.org/greenpotential.html.

Mather, D. "Compost Utilization Goes Through the Roof." BioCycle 47, no. 3 (2006): 37.

Michigan State University. "Green Roof Research Program.” Michigan State Department of Horticulture. Accessed January 4, 2011, http://www.hrt.msu.edu/greenroof/.

Peck, S.W. “The Urban Agriculture Issue.” Living Architecture Monitor 12, (2010):1-38.

Rosen, Carl J. and Roger Eliason. Nutrient Management for Commercial Fruit and Vegetable Crops in Minnesota. Department of Soil, Water, and Climate. University of Minnesota. 
2005. http://www1.extension.umn.edu/garden/fruit-vegetable/nutrient-management-forcommercial-fruit-and-vegetables-in-mn/.

Rowe, D.B., and K.L. Getter. "Green Roofs and Garden Roofs." Urban Ecosystem Ecology (2010): 391-412.

Sharp, R., J. Sable, F. Bertram, and S. Peck. "Introduction to Green Walls Technology Benefits and Design." Unpublished manuscript, Green Roofs for Healthy Cities. 2008. http://www.greenscreen.com/Resources/download_it/IntroductionGreenWalls.pdf

Snodgrass, E. C., and L. McIntyre. The Green Roof Manual: A Professional Guide to Design, Installation, and Maintenance. Portland, Oregon: Timber Press, 2010.

Snodgrass, E.C., and L.L. Snodgrass. Green Roof Plants: A Resource and Planting Guide. Portland, Oregon: Timber Press, 2006.

Tomalty, R., and B. Komorowski. "Economic Valuation of a Rooftop Food Garden." Living Architecture Monitor 12, (2010): 29-33.

VanWoert, N., B. Rowe, J. Andersen, C. Rugh, and L. Xiao. "Watering Regime and Green Roof Substrate Design Affect Sedum Plant Growth.” HortScience 40, no. 3 (2005): 659-664.

Velazquez, L.S. "Green Roofs 101 the Resource Portal for Green Roofs." Accessed March 12, 2010, http://www.greenroofs.com/.

Werthmann, C. Green Roof: A Case Study. New York: Princeton Architectural Press, 2007.

Whittinghill, L.J., D.B. Rowe, and B.M. Cregg. "Evaluation of vegetable production on extensive green roofs." Agroecology and Sustainable Food Systems. 2013. 37(4): 465484. doi: $\underline{10.1080 / 21683565.2012 .756847 .}$. 